\title{
Metastatic meningioma: a rare cause of mediastinal lymphadenopathy.
}

\author{
Hannah Louise Bond, ${ }^{1}$ Emma Maeve O'Hare, ${ }^{2}$ James Elliot Garvican, ${ }^{2}$ \\ Fiona Grace Minear ${ }^{1}$
}

${ }^{1}$ Department of Oncology, RCHT, Truro, UK

${ }^{2}$ Department of Histopathology, RCHT, Truro, UK

Correspondence to Dr Hannah Louise Bond, hannah.bond@nhs.net

HLB and EMO'H contributed equally.

Accepted 7 October 2017

\section{DESCRIPTION}

A 69-year-old man with known, stable atypical meningioma of the brain diagnosed 5 years previously presented with severe shortness of breath. The patient had previously been treated with surgery and radiotherapy to the brain. Chest X-ray revealed bulky mediastinal lymphadenopathy (figure 1). CT (figure 2) confirmed mediastinal and upper abdominal lymphadenopathy in addition to multiple pulmonary emboli. The patient underwent an endoscopic ultrasound and fine-needle aspiration (EUS-FNA), an established technique that enables prompt cytological sampling and assessment. ${ }^{1}$

The EUS-FNA preparations showed sheets and clusters of bland, polygonal epithelioid cells (figure 3). These demonstrated strong immunohistochemical positivity (figure 4) for epithelial membrane antigen. The final immunopanel was strongly supportive of metastatic meningioma.

Meningiomas are common intracranial tumours, classified by WHO into three grades based on mitotic activity and tumour differentiation. $^{2}$ Atypical (grade 2) and anaplastic (grade 3) meningiomas account for less than 5\% of all meningiomas, and metastases from these lesions are rare $(0.1 \%) .^{3}$

Due to the small number of patients with a diagnosis of metastastic meningioma, there are no established treatment pathways and the prognosis is unknown. ${ }^{3}$

The patient in our case report completed radiotherapy to the mediastinum at a dose of $30 \mathrm{~Gy}$

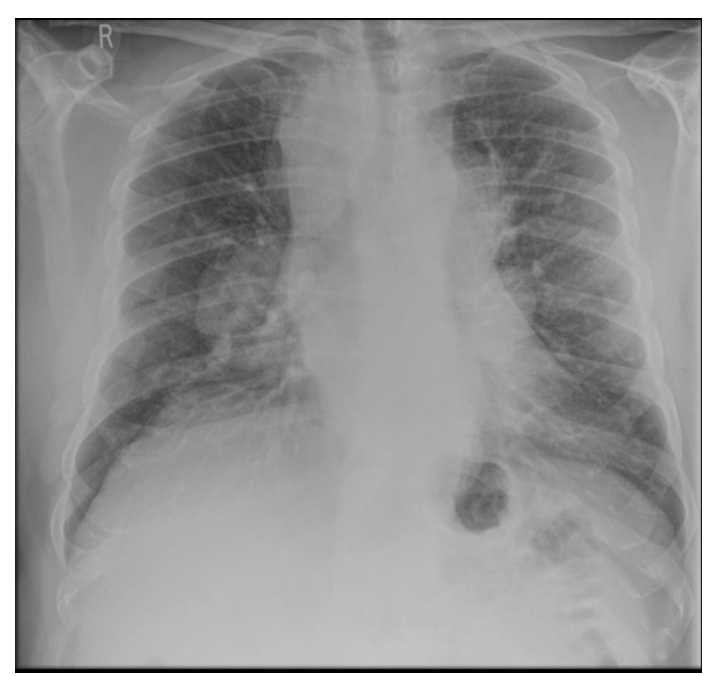

Figure 1 Chest X-ray.

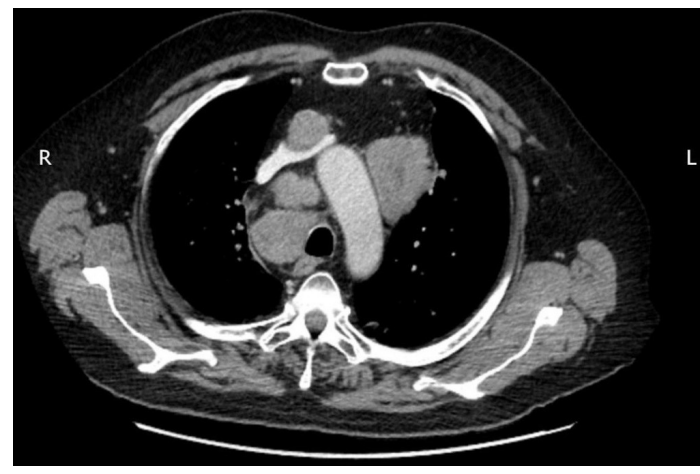

Figure 2 Contrast-enhanced CT image showing adenopathy at the level of the aortic arch.

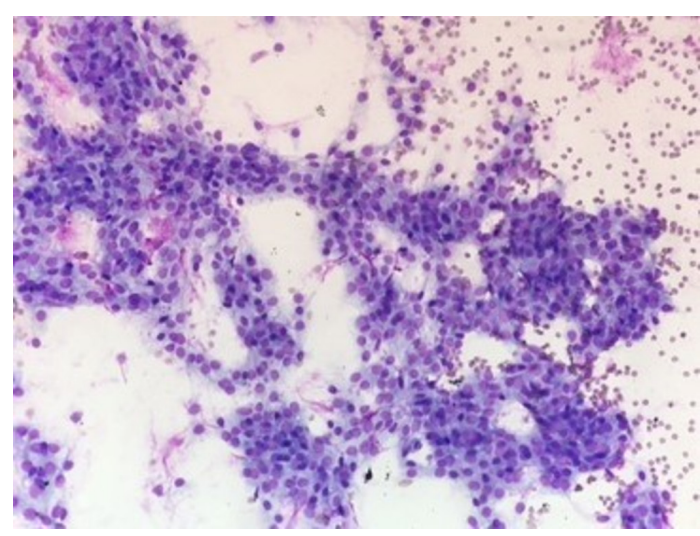

Figure 3 Endoscopic ultrasound and fine-needle aspiration cytology preparation with Giemsa stain showing bland sheets and clusters of polygonal meningioma cells.

in 10 fractions over 10 days, which improved his respiratory symptoms alongside a reducing dose of steroids. Following clinic discussion, he declined systemic treatment options and opted for palliative care.

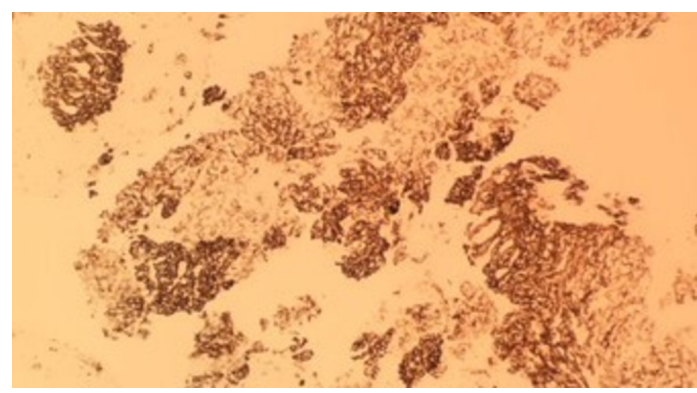

Figure 4 Immunohistochemical stain showing diffuse tumour cell positivity for epithelial membrane antigen. 
To the best of our knowledge, this is the first case in the literature of metastatic meningioma diagnosed through EUS-FNA.

\section{Learning points}

Extracranial metastases from atypical meningioma are rare.

- Evidence-based treatment options are limited.

- Endoscopic ultrasound and fine-needle aspiration can enable prompt cytological diagnosis of enlarged lymph nodes and lesions from a variety of locations in the thorax and abdomen.

Acknowledgements The authors would like to acknowledge the following peoplefor their contribution to the case study: Dr Dushyant Shetty (ConsultantRadiologist) for reviewing the radiologyimages, Ms Leonie Glinski (Senior Biomedical Scientist in Cytology) forproviding the cytology images, and Dr Aditya Shivane (Consultant Neuropathologist)for guidance regarding the patient's original diagnosis and metastaticpresentation.
Contributors HLB and EMOH contributed equally to this paper. JEG is the consultant histopathologist who reported the cytology and reached the correct diagnosis. FGM is the consultant clinical oncologist who managed the care of the patient. Both JEG and FGM provided critical appraisal of the final article.

Competing interests None declared.

Patient consent Obtained.

Provenance and peer review Not commissioned; externally peer reviewed.

(c) BMJ Publishing Group Ltd (unless otherwise stated in the text of the article) 2017. All rights reserved. No commercial use is permitted unless otherwise expressly granted.

\section{REFERENCES}

1 Costache MI, lordache S, Karstensen JG, et al. Endoscopic ultrasound-guided fine needle aspiration: from the past to the future. Endosc Ultrasound 2013;2:77-85.

2 Louis DN, Perry A, Reifenberger G, et al. The 2016 World Health Organization classification of tumors of the central nervous system: a summary. Acta Neuropathol 2016;131:803-20.

3 Kessler RA, Garzon-Muvdi T, Yang W, et al. Metastatic atypical and anaplastic meningioma: a case series and review of the literature. World Neurosurg 2017;101:47-56.

Copyright 2017 BMJ Publishing Group. All rights reserved. For permission to reuse any of this content visit http://group.bmj.com/group/rights-licensing/permissions.

BMJ Case Report Fellows may re-use this article for personal use and teaching without any further permission.

Become a Fellow of BMJ Case Reports today and you can:

- Submit as many cases as you like

- Enjoy fast sympathetic peer review and rapid publication of accepted articles

- Access all the published articles

Re-use any of the published material for personal use and teaching without further permission

For information on Institutional Fellowships contact consortiasales@bmjgroup.com

Visit casereports.bmj.com for more articles like this and to become a Fellow 